\title{
Undetectable caeruloplasmin values in a patient with autoimmune chronic active hepatitis
}

\author{
Y Ilan, M Hillman, R Oren, E Galun, M Shalit
}

\begin{abstract}
Caeruloplasmin is an alpha 2 protein produced in the liver that is responsible for transporting copper in the blood. Caeruloplasmin values are usually high in patients with chronic liver diseases, including chronic active hepatitis: low values, however, are characteristic of Wilson's disease. The case of a 17 year old woman with very low caeruloplasmin values and chronic active hepatitis of the lupoid type is described. Steroid treatment.resulted in an increase in the caeruloplasmin concentration and clinical improvement.
\end{abstract}

Caeruloplasmin is the protein responsible for copper transport in the blood. As an acute phase reactant, its concentrations are commonly raised in patients with chronic liver diseases, including chronic active hepatitis. ${ }^{1}$ Low caeruloplasmin values have been described in protein wasting states such as nephrosis and sprue and in starvation states such as kwashiorkor. ${ }^{2}$ Low caeruloplasmin concentrations have not been described in association with chronic liver disease. $^{2}$

Wilson's disease is an inherited metabolic disease that is thought to result from a biochemical defect in copper excretion via the bile, and resulting in the accumulation of copper in the liver, brain, and other tissues. Ninety five per cent of patients with Wilson's disease have serum caeruloplasmin values of less than $200 \mathrm{mg} / 1 .^{3}$

We describe a 17 year old woman who had chronic active hepatitis of the lupoid type and was found to have very low caeruloplasmin values.

\section{Case report}

A 17 year old woman was admitted to hospital for an evaluation of jaundice, arthralgia, myalgia, and fatigue which had lasted for a few months. On examination she seemed to be jaundiced, with mild splenomegaly. Neurological examination was normal, slit lamp examination did not show the presence of a Kayser-Fleischer ring or sunflower cataract. The remainder of the examination was normal.

Laboratory tests showed a sedimentation rate of $40 \mathrm{~mm}$ in the first hour, haemoglobin $109 \mathrm{~g} / \mathrm{l}$, haematocrit $32 \%$, mean corpuscular volume 100 , mean corpuscular haemoglobin 22, white blood cells $5600 / \mathrm{mm}^{3}$, prothrombin time 18 seconds (control: 11 seconds), partial thromboplastin time 60 seconds (normal 30-60 seconds). Total protein was $690 \mathrm{~g} / \mathrm{l}$, albumin $230 \mathrm{~g} / \mathrm{l}$, globulin 460 $\mathrm{g} / \mathrm{l}$, total bilirubin $83 \mathrm{mmol} / \mathrm{l}$, alkaline phosphatase $231 \mathrm{IU}$, serum alanine transaminase 789
IU, serum aspartate transaminase $850 \mathrm{IU}, \gamma$ glutamyltransferase $91 \mathrm{IU}$. Renal function tests and electrolytes were normal, with no proteinuria. HBsAg, anti-HBs IgG, anti-HBc IgG, and anti$\mathrm{HBc}$ IgM were negative. Serology for a recent hepatitis A virus, cytomegalovirus, Epstein-Barr virus, or HIV were negative. Antinuclear factors were +4, C3 $250 \mathrm{mg} / \mathrm{l}$ and antiribonucleoprotein positive; anticardiolipin, anti-DNA, antimitochondria, direct and indirect Coombs, RoseWaaler, and latex fixation were all negative. Serum IgM values $11200 \mathrm{mg} / \mathrm{l}, \mathrm{IgG} 43800 \mathrm{mg} / \mathrm{l}$, and IgA $573 \mathrm{mg} / \mathrm{l}$. The serum caeruloplasmin concentration was $0-50 \mathrm{mg} / \mathrm{l}$ on repeated examinations (normal: $180-350 \mathrm{mg} / \mathrm{l}$ ) measured by an immunological method with the use of caeruloplasmin antibody (Technicon-RA system). Serum copper values were $10 \cdot 2 \mu \mathrm{mol} / 1$ (normal: $>157 \mu \mathrm{mol} / \mathrm{l}$ ). Urine copper values were $11.8 \mu \mathrm{mol} / 24 \mathrm{~h}$ (normal: $2 \cdot 4-7 \cdot 8 \mu \mathrm{mol} / 24$ h). No copper sedimentation was found in the limbus. Abdominal ultrasound showed a pronounced inhomogeneous liver without evidence of biliary tract obstructon. A liver-spleen scan was consistent with mild diffuse hepatic parenchymal disease. Bone $x$ rays were normal.

A liver biopsy specimen was characteristic of chronic active hepatitis and copper concentration was $164 \mu \mathrm{g} / \mathrm{g}$ dry weight (normal: $<50 \mu \mathrm{g} / \mathrm{g}$; characteristic of Wilson's disease: $>250 \mu \mathrm{g} / \mathrm{g}$ ). The patient's parents and siblings were tested for serum caeruloplasmin and all were found to have concentrations greater than $200 \mathrm{mg} / \mathrm{l}$.

A diagnosis of chronic active hepatitis, lupoid type, was made and the patient was treated with steroids. After six weeks she improved symptomatically. Caeruloplasmin values increased and serum liver enzymes decreased, as shown in the Figure.

\section{Discussion}

Caeruloplasmin is an alpha 2 acute phase reactant, which is responsible for copper transport in the blood. Serum caeruloplasmin concentrations

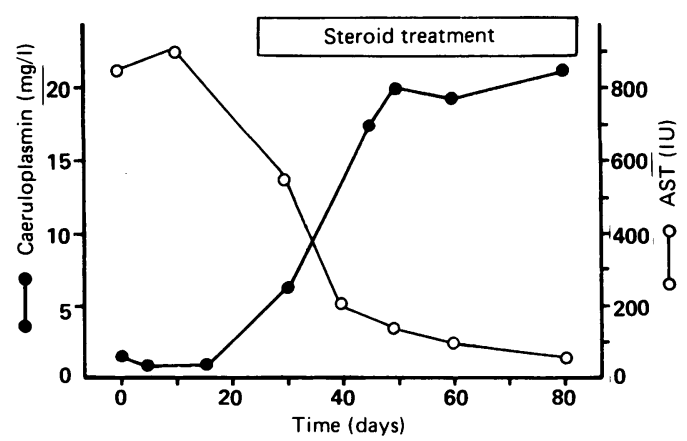

The effect of steroid treatment on serum aspartate transaminase activity and caeruloplasmin concentration. 
are often raised in chronic active hepatitis' and are characteristically depressed in Wilson's disease, fulminant hepatitis, cirrhosis, and other protein wasting states. ${ }^{3}$ Wilson's disease may be diagnosed by the presence of serum caeruloplasmin concentrations of less than $200 \mathrm{mg} / \mathrm{l}$ and either a Kayser-Fleischer ring or increased hepatic copper stores shown by liver biopsy. ${ }^{2} \mathrm{We}$ described a young patient who presented with a clinical course and laboratory data consistent with chronic active hepatitis but was found to have appreciably depressed serum caeruloplasmin concentrations. A Kayser-Fleischer ring was not found on slit lamp examination and the hepatic copper concentration was slightly raised but was not as high as the values expected in Wilson's disease. Urine copper concentrations were normal. There was no evidence of neurological involvement. Consequently, this patient did not fulfil the diagnostic criteria for Wilson's disease.

On the basis of the clinical course, the liver biopsy, and the positive antinuclear factor, the patient was diagnosed as suffering from lupus type chronic active hepatitis. The diagnosis of chronic active hepatitis was further supported by the dramatic clinical and laboratory improvement, noted within six weeks of starting steroid treatment, although mild improvement with steroid treatment is noted also in Wilson's disease. Serum caeruloplasmin concentrations, which were initially $0-50 \mathrm{mg} / \mathrm{l}$, increased to $200 \mathrm{mg} / \mathrm{l}$.
An unusual report of a heterozygous carrier of the Wilson's disease gene with unrelated chronic active hepatitis and low serum caeruloplasmin concentrations was described by Spechler and Koff.' But there was no increase in the caeruloplasmin concentration after steroid treatment, despite clinical and biochemical remission.

It is most likely that the severely depressed serum caeruloplasmin concentrations in this patient represent a selective, decreased, hepatic production. And it is unlikely that it represents severe hepatic failure. The dramatic increase in the caeruloplasmin concentration after six weeks of steroid treatment suggests an immunological basis for this selective defect. Further studies are needed to investigate this hypothesis. We conclude that depressed serum caeruloplasmin concentrations may be seen in lupoid type chronic active hepatitis in the absence of Wilson's disease.

1 Walshe JM, Briggs J. Caeruloplasmin in liver disease: a

2 Walshe JM. Copper: its role in the pathogenesis of liver disease. Semin Liver Dis 1985; 4: 252-6.

3 Uzmain LL. The mechanism of copper deposition in the liver in hepatotenticular degeneration. Am $\mathcal{F}$ Med Sci 1956; 231: 511-3. 4 Sternlieb I. Diagnosis of Wilson's disease. Gastroenterology
1978; 74: 787-9.

5 Sternlieb I, Scheinberg IH. Chronic hepatitis as a first manifestation of Wilson's disease. Ann Intern Med 1972; 16: 59-64.

6 Scott J, Gullan JL, Samourian S. Wilson's disease presenting a chronic active hepatitis. Gastroenterology 1978; 74: 645-51

7 Spechler SJ, Koff RS. Wilson's disease: diagnostic difficulties in the patient with chronic hepatitis and hypoceruloplas-
minemia. Gastroenterology 1980; 78: 803-6. 